\title{
PERLINDUNGAN HUKUM TERHADAP PEMEGANG SAHAM MINORITAS DARI PENGGABUNGAN PERUSAHAAN (MERGER) PADA PERSERON TERBATAS DI INDONESIA
}

\author{
${ }^{1}$ Muhammad Rizki, ${ }^{2}$ Hamdani, ${ }^{2}$ Ramziati \\ Co. Author :ramziati@unimal.ac.id \\ ${ }^{1}$ Mahasiswa Fakultas Hukum, Universitas Malikussaleh \\ 2 Dosen Fakultas Hukum Universitas Malikussaleh
}

\begin{abstract}
This study aims to explain the position of minority shareholders as interested parties and the legal protection against them from the merger of Limited Liability Companies in Indonesian Laws and Regulations. Merger is a restructuring that is often carried out to improve company performance, therefore there is a need for legal protection for minority shareholders because their position with the principle of one share one vote in decision making on mergers in the GMS is weaker than the majority shareholders Minority shareholders who do not agree with the merger are given the right to sell their shares at a fair price but do not stop the merger process. The method used in this research is normative juridical. The approach used in this research is a statutory approach, namely research that prioritizes legal materials in the form of statutory regulations as a basic reference for conducting research. From the results of the study, it is known that the position of minority shareholders is weaker than the majority in the RUPS, due to the number of share ownership. minority shareholders who do not agree with the merger will be granted an appraisal right, namely the right to sell their shares at a fair price in Article 126 paragraph (2). However, the merger process is still ongoing, which shows that legal remedies by minority shareholders cannot stop the merger process. So that the Company Law has not been able to provide clear legal protection to accommodate the rights and interests of minority shareholders who were disadvantaged in the merger process as required in the principles of Good Corporate Governance (GCG). It is advisable to revise or add to the Company Law in terms of the merger of the Company to be better able to accommodate the rights and interests of minority shareholders towards the merger due to the position of minority shareholders who are still difficult to exercise their rights and interests in the merger, especially in closed companies, to encourage the application of GCG principles so as to guarantee justice and legal certainty for minority shareholders
\end{abstract}

Keywords: Legal Protection, Minority Shareholders, Merger 


\section{PENDAHULUAN}

Perseroan Terbatas (PT) merupakan salah satu bentuk perusahaan yang kebanyakan digunakan di Indonesia, dikarenakan memiliki keistimewaan yang tidak dimliki oleh bentuk perusahaan lainnya, misalnya bentuk Perseroan yang badan hukum, karena bentuknya yang badan hukum maka PT ialah subjek hukum yang mandiri, sebagaimana orang perorangan yang memiliki kecakapan untuk bertindak dan mempertahankan haknya didalam hukum. ${ }^{1}$

Perubahan signifikan dalam lingkungan bisnis seperti globalisasi, deregulasi, kemajuan teknologi serta fragmentasi pasar telah menciptakan persaingan yang sangat ketat (fierce competition). Respon perusahaan-perusahaan terhadap meningkatnya persaingan sangat beragam,sebagian perusahaan memilih untuk memfokuskan sumber daya ekonomi yang dimiliki pada segmen tertentu yang lebih kecil, sebagian tetap bertahan dengan strategi usaha yang dilakukan sebelumnya dan sebagian menggabungkan diri dengan perusahaan lainnya menjadi satu perusahaan yang lebih besar di dalam pasar(restrukturisasi).

Restrukturisasi usaha merupakan pilihan strategi kegiatan usaha yang dapat atau bisa dilakukan oleh suatu PT, restrukturisasi dilakukan perusahaan dengan harapan agar kinerja keuangan perusahaan dapat meningkat, salah satu tolak ukur kinerja keuangan perusahaan adalah rasio keuangan, dimana untuk menciptakan keadaan usaha yang sehat maka pelaku usaha sebagai subjek ekonomi senantiasa berusaha untuk dapat memaksimalkan keuntungan dalam mengelola perusahaannya sehingga restrukturisasi perusahaan adalah solusi yang tepat untuk membantu PT yang mengalami kemunduran untuk meningkatkan efisiensi dan eksistensi perusahaannya. ${ }^{2}$

Undang-Undang Nomor 40 Tahun 2007, tentang Perseroan Terbatas (UUPT) telah mengatur bentuk-bentuk Restrukturisasi PT yang dibenarkan hukum. Terdiri atas Penggabungan (Merger), Pengambilalihan (Akuisisi), Peleburan (Konsolidasi), dan Pemisahan Perseroan (Spin Off) Terbatas. Namun peneliti hanya akan fokus terhadap kajian tentang Penggabungan (Merger) PT. Pasal 1 angka 9 UUPT Tentang PT menggunakan istilah "penggabungan", sebagai pengganti terminology "merger", mengatur: "Penggabungan adalah perbuatan hukum yang dilakukan oleh satu Perseroan atau lebih untuk menggabungkan diri dengan Perseroan yang lain yang telah ada yang mengakibatkan aktiva dan pasiva dari Perseroan yang menggabungkan diri beralih karena hukum kepada Perseroan yang menerima penggabungan dan selanjutnya status badan hukum Perseroan

\footnotetext{
${ }^{1}$ M.Yahya Harahap, Hukum Perseroan Terbatas, Sinar Grafika, Jakarta,2009, hlm 24-25.

${ }^{2}$ Dewi Nurjanah, Pengaruh Pemilihan Metode Untuk Merger dan Akuisisi Terhadap Volume Perdagangan Saham Perusahaan Publik yang Terdaftar di BEJ Periode 2000-2006, Skripsi Fakultas Ekonomi UMS, 2007, hlm. 1
} 
yang menggabungkan diri berakhir karena hukum"3 Pengertian yang dikemukakan pada Pasal 1 angka 9 UUPT 2007, hampir sama dengan yang dirumuskan pada Pasal 1 angka 1 Peraturan Pemerintah Nomor 27 Tahun 1998 tentang Penggabungan, Peleburan, dan Pengambilalihan Perseroan Terbatas (yang selanjutnya akan disebut PP Nomor 27 Tahun 1998) tetapi lebih singkat yang berbunyi : "Penggabungan adalah perbuatan yang dilakukan oleh satu Perseroan atau lebih untuk menggbungkan diri dengan Perseroan lain yang telah ada dan selanjutnya Perseroan yang menggabungkan diri bubar". 4

Marcel Go mengemukakan, bahwa merger ialah suatu proses penggabungan Perseroan, suatu Perseroan mengambil alih satu ataupun lebih Perseroan yang lain. Setelah diambil alih maka Perseroan yang diambil alih dibubarkan atau dilikuidasi sehingga eksistensinya sebagai badan hukum lenyap. Maka dengan demikian terhadap kegiatan usahanya dilanjutkan oleh Perseroan yang mengambil alih. ${ }^{5}$

Merger merupakan wujud dari penyerapan oleh satu perusahaan akan perusahaan lain. Jika dua perusahaan A dan B, melaksanakan merger, hanya akan tersisa satu perusahaan saja, yaitu A atau B. Dalam sebagian besar permasalahan merger, dimana perusahaan yang mempunyai ukuran lebih besar akan dipertahankan hidup serta tetap mempertahankan nama dan status hukumnya, sebaliknya perusahaan yang mempunyai ukurannya lebih kecil (perusahaan yang dimerger) akan menghentikan kegiatannya ataupun dibubarkan sebagai badan hukum.

Dalam merger perlu diketahui Syarat-syarat yang harus dipenuhi sehingga suatu perusahaan dapat melakukan merger dengan perusahaan lainnya, Syarat yang pertama menurut Pasal 126 ayat (1) UUPT 2007 jo. Pasal 4 ayat (1) PP Nomor 27 Tahun 1998, penggabungan tidak boleh dilaksanakan apabila merugikan kepentingan pihak-pihak tertentu, yaitu kepentingan Perseroan, pemegang saham minoritas (PS minoritas), karyawan Perseroan, kepentingan kreditor, mitra usaha lainnya dari Perseroan, kepentingan masyarakat dan persaingan sehat dalam melakukan usaha. Syarat yang kedua yaitu berdasarkan penjelasan Pasal 123 ayat (4) UUPT 2007, bagi Perseroan tertentu yang akan melakukan penggabungan harus memperoleh persetujuan dari instansi terkait.

Salah satu akibat dari struktur saham yaitu terciptanya struktur pemegang saham mayoritas dan minoritas, pembedaan antara pemegang saham pada suatu PT membuat kedudukan minoritas menjadi lemah dikarenakan UUPT yang menganut asas ataupun paham one share one vote, sehingga tanggung jawab daripada PS minoritas pada hakikatnya terbatas karena hanya bertanggung jawab sampai jumlah saham yang dimiliki (one share one vote), Dikarenakan pola pengambilan keputusan didasarkan atas besarnya

3 Republik indonesia, Pasal 1 angka 9, Undang-Undang Nomor 40 Tahun 2007, tentang Perseroan Terbatas

4 Republik indonesia, Pasal 1 angka 1, Peraturan Pemerintah Nomor 27 Tahun 1998 tentang Penggabungan, Peleburan, dan Pengambilalihan Perseroan Terbatas,

${ }^{5}$ Marcel Go, Akuisisi bisnis dan pengelolaan. Rineka Cipta, Jakarta, 1992. hlm. 25-26. 
persentase saham yang dimiliki maka bisa dipastikan dalam mekanisme pengambilan keputusan di perusahaan PS minoritas akan selalu kalah dibandingkan PS mayoritas.

PS minoritas yang tidak menyetujui pelaksanaan merger selalu mengalami kesulitan untuk melaksanakan hak-haknya terutama dalam rangka meminta pertanggungjawaban dari Perseroan. Terkadang tindakan merger yang dianggap merugikan tersebut, oleh Direksi/Komisaris atau PS mayoritas justru dianggap sebagai suatu tindakan yang paling tepat bagi Perseroan. Ditambah tidak adanya penjelasan lebih lanjut mengenai kriteria "saham dengan harga yang wajar" dalam peraturan tersebut atau peraturan pelaksananya, sehingga hal ini dapat menimbulkan multitafsir dan berpotensi menimbulkan kerugian terhadap PS minoritas ditambah merger tetap dilaksanakan tanpa persetujuan PS minoritas. Keadaan demikian tidak menguntungkan dikarenakan dengan mengambil permintaan pembelian kembali saham dengan harga yang wajar kepada Perseroan maka PS minoritas melepaskan hak atas saham yang dimilikinya, dimana kemungkinan hal tersebut terjadi (PS minoritas menjual sahamnya dengan harga wajar) karena keadaan terpaksa yang sengaja di kondisikan oleh PS mayoritas yang tidak beritikad baik. Sehingga hak-hak yang tersebut diatas belum mencerminkan perlindungan hukum yang sesuai dengan prinsip-prinsip yang terkandung didalam Good Corporate Governance (GCG). Maka sudah seharusnya perlindungan hukum terhadap PS minoritas tidak boleh dibaikan baik perlindungan hukum yang bersifat represif maupun juga preventif yang bertujuan mencegah terjadinya pelanggaran (sengketa) yang merugikan PS minoritas

Tujuan dari penelitian ini adalah untuk menjelaskan ba gaimana kedudukan pemegang saham minoritas sebagai pihak yang berkepentingan dalam penggabungan perusahaan (merger) pada Perseroan Terbatas serta bentuk perlindungan hukum terhadapnya dalam Peraturan Perundang-undangan di Indonesia.

\section{METODE PENELITIAN}

Penelitian ini adalah penelitian yuridis normatif dengan sifat penelitian deskriptif analisis. Pendekatan penelitian yang digunakan dalam penelitian ini adalah Pendekatan Perundang-undangan (Statute Approach). Pendekatan ini dilakukan untuk peneliti menggunakan peraturan perundang- undangan sebagai dasar awal untuk melakukan analisis. Data yang digunakan adalah data sekunder yang terdiri dari bahan hukum primer, bahan hukum sekunder, dan bahan hukum tersier. Data yang terkumpul kemudian dianalis secara kualitatif.

Adapun rumusan masalah dalam penelitian ini adalah :

1. Bagaimanakah kedudukan pemegang saham minoritas sebagai pihak yang berkepentingan dalam penggabungan perusahaan (merger) pada Perseroan Terbatas ?

2. Bagaimanakah bentuk perlindungan hukum terhadap pemegang saham minoritas dari penggabungan perusahaan (merger) pada Perseroan Terbatas dalam peraturan perundang-undangan indonesia ? 


\section{HASIL PENELITIAN DAN PEMBAHASAN}

\section{Kedudukan Pemegang Saham Minoritas Sebagai Pihak Yang Berkepentingan Dalam Penggabungan Perusahaan (Merger) Pada Perseroan Terbatas}

Menjalankan perbuatan hukum seperti merger merupakan hal yang lazim dilakukan oleh Perseroan dalam rangka memperoleh hasil yang lebih baik. Maka merger sebagai perbuatan hukum selayaknya dapat memberikan dampak baik kepada pihak berkepentingan (PS minoritas) maupun pihak lainnya. Pada dasarnya kepentingan PS minoritas ditinjau dari 2 aspek:

1. Kepentingan pribadinya terhadap Perseroan berdasarkan hak perseorangan (personal rights)

2. Kepentingannya sebagai bagian Perseroan (derivative rights), khususnya Rapat Umum PS terhadap tindakan dari organ Perseroan lainnya, yaitu direksi dan komisaris. ${ }^{6}$

Sebagai perbuatan hukum, maka merger harus memperhatikan kedudukan pihakpihak yg berkepentingan tanpa terkecuali kepentingan PS khususnya PS minoritas. Meskipun telah diatur terkait dengan tanggung jawab dari organ-organ Perseroan dan juga PS, dalam praktiknya sering timbul perselisihan di antara organ Perseroan dengan PS atau bisa terjadi di antara PS sendiri. Dikarenakan perbedaan antara PS mayoritas dengan PS minoritas adalah dalam hal jumlah kepemilikan saham, sehingga membuat PS minoritas seringkali berada di posisi yang lemah dalam menegakkan kepentingan dan haknya, Di karenakan kedudukan PS minoritas dengan prinsip one share one vote terkait dengan pengambilan keputusan dalam rancangan merger Perseroan pada RUPS lebih lemah dari PS mayoritas. Oleh sebab itu dengan terpaksa PS minoritas harus mengikuti suara dari mayoritas yang mengabulkan rancangan merger tersebut. Dengan kepemilikan jumlah saham lebih sedikit posisi PS minoritas lebih lemah dalam menghadapi tindakan yang merugikan dirinya dan kepentingannya, dikarenakan PS mayoritas identik dengan Direksi ataupun Komisaris selaku organ dalam Perseroan. PS minoritas yang tidak setuju atas tindakan merger tersebut hanya dapat menggunakan haknya agar sahamnya dibeli dengan harga yang wajar (appraisal rights), namun langkah tersebut tidak menghalangi proses pelaksanaan merger tersebut. Sedangkan permintaan pembelian kembali saham dengan harga yang wajar kepada Perseroan belum tentu diambil oleh PS minoritas karena dengan menempuh cara ini maka PS minoritas menyerahkan hak atas sahamnya, ini jelas tidak fair.

Kedudukan pemegang saham minoritas dengan prinsip one share one vote berkaitan dengan pengambilan keputusan pada RUPS lebih lemah dari pemegang saham mayoritas. Dikarenakan kedudukan pemegang saham minoritas sangat rentan terhadap kerugian, maka dalam halnya merger perusahaan terhadapnya perlu mendapat perlindungan hukum yang jelas dan memadai. Ini disebabkan pemegang saham minoritas merupakan

\footnotetext{
${ }^{6}$ Adrian Sutedi. Buku Pintar Hukum Perseroan Terbatas, Raih Asa Sukses. Jakarta 2015, hlm. 202
} 
pihak yang rawan eksploitasi oleh pihak lainnya. Agar terpenuhinya unsur kea dilan pihak pemegang saham minoritas perlu diperhatikan kepentingannya dan tidak bisa begitu saja diabaikan haknya. Perlindungan hukum tersebut dapat kita lihat dari beberapa pasal yang ada pada UUPT, baik kepentingan pribadi pemegang saham maupun kepentingannya sebagai bagian Perseroan, dari perbuatan/tindakan yang dilakukan oleh organ Perseroan.

Sebagai salah satu organ PT, PS memiliki status hukum yang kuat secara yuridis, dikarenakan ikatan financial tersebut membuat keadaan PS minoritas ini menjadi lebih lemah daripada PS lainnya. Dalam perihal ini kembali sektor hukum diminta perannya dalam menjaga keadilan serta kesetaraan hukum terhadap PS minoritas sampai dengan batas tertentu. Mengingat adanya benturan antara berbagai kepentingan PS mayoritas dan PS minoritas, maka perlindungan terhadap PS minoritas begitu penting terhadap hukum merger, maka PS minoritas perlu diangkat dari keterpurukannya sehingga kepadanya tercapai unsur fairness, sebagaimana di isyaratkan oleh prinsip $G C G$

\section{Bentuk Perlindungan Hukum Terhadap Pemegang Saham Minoritas Dari Penggabungan Perusahaan (Merger) Pada Perseroan Terbatas Dalam Peraturan Perundang-Undangan Di Indonesia}

UUPT memuat ketentuan yang memberikan perlindungan hukum terhadap PS apabila tidak setuju atas merger PT, diberikan hak khusus yang disebut appraisal right, hak tersebut diatur dalam Pasal 126 ayat (2) juncto Pasal 62 UUPT yaitu hak untuk menjual sahamnya PS yang untuk menjual sahamnya kepada Perseroan dengan harga yang wajar.

Pasal 126 ayat (2) "Pemegang saham yang tidak setuju terhadap keputusan RUPS mengenai penggabungan, peleburan, pengambilalihan dan pemisahan sebagaimana dimaksud pada ayat (1) hanya boleh menggunakan haknya sebagaimana dimaksud dalam Pasal 62". Pasal ini menjelaskan bahwa pemegang saham yang tidak menyetujui penggabungan, peleburan, pengambilan atau pemisahan berhak meminta kepada Perseroan agar sahamnya dibeli sesuai dengan harga wajar saham dari Perseroan sebagaimana dimaksud dalam penjelasan Pasal 123 ayat (2) huruf c dan 125 ayat (6) huruf d. ${ }^{7}$

Selanjutnya Pasal 62 ayat (1) Setiap pemegang saham berhak meminta kepada Perseroan agar sahamnya dibeli dengan harga wajar apabila yang bersangkutan tidak menyetujui tindakan Perseroan yang merugikan pemegang saham atau Perseroan, berupa:

a. Perubahan anggaran dasar;

b. Pengalihan atau penjaminan kekayaan Perseroan yang memounyai nilai lebih dari $50 \%$ (lima puluh persen) kekayaan bersih dari Perseroan; atau

c. Penggabungan, peleburan, pengambilalihan dan pemisahan.

(2) Dalam hal saham yang diminta untuk dibeli kembali sebagaimana dimaksud pada ayat (1) melebihi batas ketentuan pembelian kembali saham oleh Perseroan sebagaimana

\footnotetext{
${ }^{7}$ Republik indonesia, Pasal 126 angka 2, Undang-Undang Nomor 40 Tahun 2007, tentang Perseroan Terbatas
} 
dimaksud dalam Pasal 37 ayat (1) huruf b, Perseroan wajib mengusahakan agar sisa saham dibeli oleh pihak ketiga. ${ }^{8}$

Dalam perkembangannya, institusi hak appraisal right ini sebenarnya mempunyai dua fungsi yuridis sebagai berikut:

1. Berfungsi sebagai jalan keluar bagi PS minoritas untuk keluar dari perusahan yang sudah berubah secara fundamental, di mana dia tidak setuju terhadap perubahan dimaksud.

2. Berfungsi sebagai penjaga keadilan bagi PS yang dengan menggunakan institusi hukum berupa hak appraisal ini, mencoba mengusir pihak PS minoritas dari perusahaan dengan merancang suatu perubahan prinsipil yang tidak disenangi atau bahkan merugikan pihak PS minoritas. Pengusiran tersebut umumnya dilakukan dengan cash out merger atau juga disebut take out merger. Merger untuk menekan pihak PS minoritas yang disebut dengan istilah "cash out merger" atau "take out merger" ini mulai marak dilakukan secara universal sejak dekade 1970-an. Dewasa ini, dimana-mana hak appraisal lebih banyak digunakan oleh PS minoritas didalam perusahaan yang merger seperti itu. ${ }^{9}$

Berdasarkan ketentuan diatas dapat disimpulkan bahwasanya apabila PS minoritas tidak menyetujui keputusan mengenai merger hanya boleh menggunakan haknya untuk meminta kepada Perseroan agar sahamnya dibeli dengan harga yang wajar (sesuai pasal 62). Menjadi pertanyaan bagaimana kriteria harga yang wajar tersebut, dikarenakan UUPT tak menentukan secara jelas kriteria harga yang wajar tersebut. ketentuan mengenai kriteria harga saham yang wajar menjadi penting karena dominannya PS mayoritas dalam keputusan terhadap merger dalam RUPS, berpotensi merugikan kepentingan PS minoritas. Sangat mungkin terjadi bahwa PS minoritas menjual sahamnya karena keadaan terpaksa yang sengaja di kondisikan oleh PS mayoritas yang tidak beritikad baik. ditambah merger akan tetap dilaksanakan bahkan tanpa persetujuan PS minoritas sekalipun, sementara permohonan PS minoritas yang tidak menyetujui dilakukannya merger bisa mengajukan penawaran agar Perseroan membeli sahamnya dengan harga yang wajar masih diproses, pelaksanaan merger itu sendiri telah diputuskan melalui RUPS. Perihal ini disebabkan PS mayoritas memiliki kourum jumlah suara yang dapat mengambil keputusan dalam RUPS. Tentunya hal ini membuat posisi PS minoritas posisi tidak enak dan tidak menguntungkan dikarenakan dengan mengambil permintaan pembelian kembali saham dengan harga yang wajar kepada Perseroan maka PS minoritas melepaskan hak atas sahamnya. sangat mungkin terjadi bahwa PS minoritas menjual saham tersebut karena keadaan terpaksa yang sengaja di kondisikan oleh PS mayoritas yang tidak beritikad baik.

Mengingat adanya berbagai kepentingan pihak PS mayoritas yang saling bertentangan dengan PS minoritas tersebut, maka hukum perlu mencari suatu equilibrium

\footnotetext{
${ }^{8}$ Republik indonesia Pasal 62, Undang-Undang Nomor 40 Tahun 2007, tentang Perseroan Terbatas

${ }^{9}$ Munir Fuady, Perlindungan Pemegang Saham Minoritas, CV Utomo, Bandung, 2005 hlm. 192
} 
(keseimbangan), yang kemudian equalibrium tersebut muncul dalam prinsip majority rule minority protection tersebut, ini dikarenakan, pihak PS minoritas perlu diangkat dari keterpurukannya sehingga kepadanya tercapai unsur fairness, sebagaimana di isyaratkan oleh prinsip $G C C$.

Terhadap Perseroan terbuka Perlindungan hukum terhadap PS minoritas juga diatur dalam UUPM mengatur perlindungan terhadap PS minoritas walaupun tidak spesisfik, UUPM menyebutkan bahwasanya PS minoritas tidak dapat diabaikan kepentingan oleh pihak manapun termasuk PS mayoritas, Diantaranya yaitu dalam hal:

\section{Perlindungan terhadap Transaksi Benturan Kepentingan}

Undang-Undang Republik Indonesia Nomor 8 tahun 1995 tentang pasar Modal yang selanjutnya disebut UUPM maupun peraturan perundang-undangan dibawahnya juga ikut pula mengatur mengenai upaya perlindungan terhadap pemegang saham minoritas, yaitu dalam bentuk: Pasal 82 ayat (2) UUPM jo. peraturan Bapepam Nomor IX.E.1 tahun 2008 tentang pengaturan terhadap transaksi yang mengandung benturan kepentingan tertentu (conflict of interest) secara jelas dalam UUPM yaitu dalam Pasal 82 ayat (2) UUPM pemegang saham minoritas terlindungi dalam hal terjadinya transaksi berbenturan kepentingan, tetapi dalam pasal tersebut keterlibatan pemegang saham minoritas tidak mutlak, hal ini dikarenakan dalam pasal tersebut UUPM hanya memberi otoritas kepada Bapepam (sekarang OJK) untuk "Dapat"mewajibkan, jadi dalam hal ini dapat disimpulkan bahwa otoritas sepenuhnyaada di Bapepam, bukan UUPM. ${ }^{10}$

Pasal 82 ayat (2) UUPM dibawah ini: "Bapepam dapat mewajibkan emiten atau perusahaan publik untuk memperoleh persetujuan pemegang saham independen untuk secara sah dapat melakukan transaksi yang berbenturan kepentingan, yaitu antara emiten atau perusahaan publik dengan kepentingan ekonomis pribadi direksi atau komisaris atau juga pemegang saham utama emiten atau perusahaan publik"

Peraturan Nomor IX.E.1 tentang Transaksi Afiliasi dan Benturan Kepentingan Transaksi Tertentu, Keputusan Ketua Bapepam (sekarang OJK) dan LK Nomor Kep412/BL/2009 (selanjutnya disebut "Peraturan Nomor IX.E.1"), pada angka 3 huruf a menyebutkan bahwa, "transaksi yang mengandung Benturan Kepentingan wajib terlebih dahulu disetujui oleh para Pemegang Saham Independen atau wakil mereka yang diberi wewenang untuk itu dalam RUPS sebagaimana diatur dalam Peraturan ini. Persetujuan mengenai hal tersebut harus ditegaskan dalam bentuk akta notariil." 11

\footnotetext{
${ }^{10}$ Syofia Gayatri, Sunaryo, Dianne Eka R, Perlindungan Hukum Terhadap Pemegang Saham Minoritas Pada Perusahaan Terbuka Di Indonesia , Pactum Law Journal ,Vol 1 No. 2 ,2018

${ }^{11}$ Menurut Peraturan Nomor IX.E.1 tentang Transaksi Afiliasi dan Benturan Kepentingan Transaksi Tertentu, Keputusan Ketua Bapepam dan LK Nomor Kep-412/BL/2009, transaksi adalah aktivitas dalam rangka : 1) memberikan dan/ atau mendapat pinjaman ; 2) memperoleh, melepaskan, atau menggunakan aset termasuk dalam rangka menjamin ; 3) memperoleh, melepaskan, atau menggunakan jasa atau Efek suatu Perusahaan atau Perusahaan Terkendali ; atau 4) mengadakan kontrak sehubungan dengan aktiv itas sebagaimana dimaksud dalam butir 1), butir 2), dan butir 3),
} 
2. Peraturan Otoritas Jasa Keuangan Nomor 74/POJK.04/2016 tentang penggabungan usaha atau peleburan usaha perusahaan terbuka

Untuk melindungi kepentingan PS minoritas perusahaan terbuka dalam kaitannya dengan perbuatan hukum merger (penggabungan usaha) dan konsolidasi (peleburan usaha), peraturan dibidang pasar modal mensyaratkan :

a. Penggabungan usaha ataupun peleburan usaha wajib memperoleh persetujuan RUPS perusahaan terbuka dengan memenuhi kuorum mayoritas super atau 3/4 bagian dari jumlah hak suara yang sah (Pasal 17 ayat (1) Peraturan Otoritas Jasa Keuangan Nomor 74/POJK.04/2016 tentang penggabungan usaha atau peleburan usaha perusahaan terbuka jo. Pasal 28 POJK N omor 32/POJK.04/2014). Dengan kuorum mayoritas super tersebut, keputusan tidak bisa diambil tanpa melibatkan PS minoritas mengingat kuorum yang ditentukan tersebut besar.

b. Penyelenggaraan RUPS independen apabila transaksi merger serta konsolidasi tersebut termasuk transaksi yang mengandung unsur benturan kepentingan (sesuai Peraturan IX.E.1).

c. Emiten ataupun perusahaan publik yang melakukan pengabungan, peleburan atau pengambilalihan perusahaan lain wajib mengikuti ketentuan-ketentuan mengenai keterbukaan, kewajaran dan pelaporan yang sesuai ketetapan Bapepam (sekarang OJK) dan peraturan perundang-undangan lainnya yang berlaku. (Pasal 84 UUPM jo. Peraturan Otoritas Jasa Keuangan Nomor 31/POJK.04/2015 tentang Keterbukaan atas Informasi atau Fakta Material oleh Emiten atau Perusahaan Publik).

d. Pemberian appraisal rights bagi PS minoritas yang tidak menyetujui merger serta konsolidasi tersebut. Pasal 2 ayat (2) POJK Nomor 74/POJK.04/2016 menyatakan bahwa ketentuan dalam UUPT berkaitan dengan penggabungan (merger) ataupun peleburan usaha (konsolidasi), sepanjang tidak diatur secara khusus dalam POJK Nomor 74/POJK.04/2016, tetap berlaku bagi perusahaan. Sehingga PS minoritas dapat menggunakan hak yang dimilikinya sesuai Pasal 62 UUPT untuk meminta pada Perseroan agar sahamnya dibeli dengan harga yang wajar. ${ }^{12}$.

UUPM merupakan sumber hukum yang kedua dalam suatu PT yang go publik atau yang sudah melakukan penawaran dilantai bursa efek, pada intinya perbedaan antara Perseroan tertutup dengan Perseroan terbuka hanyalah proses penawaran saham yang dimiliki. Namun kedudukannya sangat penting dikarenakan dapat mengesampingkan UUPT sendiri jika pokok aturannya sama (lex specialis derogat lex generalis), hal ini dapat dilihat dari Pasal 154 ayat (1) UUPM: "Bagi Perseroan Terbuka berlaku ketentuan Undang-

yang dilakukan dalam satu kali transaksi atau dalam suatu rangkaian transaksi untuk suatu tujuan atau kegiatan tertentu. (angka 1 huruf c)

${ }^{12}$ Wina Bismar Nasution, Suhaidi, Mahmul Siregar, Analisis Yuridis Perlindungan Hukum terhadap Pemegang Saham Minoritas dalam Perusahaan Terbuka, USU Law Journal, Vol.6. No.5 (Oktober 2018) 
Undang ini jika tidak diatur lain dalam peraturan perundang-undangan dibidang pasar modal". Namun tidak serta merta dapat mengesampingkan, namun harus sesuai dengan asa yang terkandung dalam UUPT. Apabila asas yang digunakan bertentangan maka UUPT tetap berlaku. Hal ini senada dengan bunyi Pasal 154 ayat (2) UUPM: "Peraturan perundang-undangan di bidang pasar modal yang mengecualikan ketentuan UndangUndang ini tidak boleh bertentangan dengan asas hukum Perseroan dalam Undang-Undang ini. $^{13}$

Dari uraian di atas jelas bahwa UUPM dan perangkat hukum di bidang pasar modal sangat besar andilnya dalam pengaturan Perseroan selama tidak ada pertentangan asas yang digunakan. Dalam kaitannya dengan perlindungan pemegang saham minoritas, perangkat hukum di bidang pasar modal hanya sedikit mengaturnya, karena mengenai perlindungan pemegang saham minoritas sudah terwakili oleh UUPT.

3. Prinsip Good Corporate Governance (GCG) terhadap Perlindungan Hukum Pemegang Saham Minoritas

GCG pada dasarnya ialah suatu mekanisme yang mengatur tentang tata cara pengelolaan prusahaan berdasarkan aturan-aturan yang menaungi perusahaan tersebut seperti halnya Anggaran Dasar, UUPT, dan aturan-aturan tentang kegiatan perusahaan dalam menjalankan perusahaannya. Adanya GCG ini muncul dari ide dasar yaitu, Pertama; untuk membedakan fungsi dan kepentingan di antara pihak-pihak dalam perusahaan yaitu pihak yang menyediakan modal atau PS, pengawas, dan pelaksana sehari-hari perusahaan dan masyarakat luas. Kedua; untuk melindungi kepentingan PS minoritas dalam pengelolaan perusahaan. Komponen PS minoritas merupakan salah satu pihak penting, karena Indonesia adalah negara berkembang dimana mempunyai jumlah penduduknya termasuk paling besar di dunia, dimana potensi masyarakatnya dalam kemampuan membeli masih dalam jumlah kecil. Dengan pendapatan perkapita yang masih belum tinggi, potensi penduduk Indonesia hanya memiliki saham yang tentunya juga tidak besar. Maka dari itu, perlindungan PS minoritas menjadi begitu penting. ${ }^{14}$

Pada prinsipnya perlindungan hukum kepada pemegang saham minoritas diatur dalam GCG yang meliputi:

1. Asas Keadilan

yaitu persamaan perlakuan terhadap seluruh PS, termasuk PS minoritas dimana harus mempunyai kesempatan yang sama dalam mendapatkan penggantian atau perbaikan atas pelanggaran dari hak-hak PS.

2. Asas Transparansi

\footnotetext{
${ }^{13}$ Aripin, Perlindungan Hukum Terhadap Pemegang Saham Minoritas Perseroan Terbatas Terbuka Dalam Rangka Menciptakan Kepastian Hukum Sebagai Sarana Peningkatan Iklim Investasi Di Indonesia,skripsi,2009, Fakultas Hukum Universitas Sebelas Maret Surakarta

${ }^{14}$ Hasnati, Peranan Komite Audit dalam Organ Perseroan Terbatas dalam Kerangka Good Corporate Governance, FH UII Press, Yogyakarta, 2004, hlm. 56-57
} 
yaitu adanya keterbukaan dalam pelaksanaan proses pengambilan keputusan dan keterbukaan didalam mengemukakan informasi materiil dan relevan mengenai perusahaan.

3. Asas Akuntabilitas

yaitu kejelasan fungsi, pelaksanaan dan pertanggungjawaban organ perusahaan kepada PS dan stakeholder lainnya sehingga pengelolaan perusahaan dapat terlaksana dengan efektif

4. Asas Responsibilitas

yaitu perusahaan harus berpegang pada hukum yang berlaku dan melakukan kegiatan dengan bertanggungjawab kepada seluruh stakeholder serta terhadap masyarakat, yaitu dengan tidak melakukan tindakan yang dapat merugikan para stakeholder tersebut. ${ }^{15}$

Keempat asas dalam GCG diatas merupakan norma dasar hukum perusahaan secara umum dan perlindungan hukum PS minoritas secara khusus harus ada dan diterapkan dalam hukum perusahaan di Indonesia khususnya. Melalui konsep GCG, PS dan pemangku kepentingan diberikan hak dan kewenangan yang proposional untuk mengetahui keadaan serta meminta pertanggungjawaban pihak-pihak yang menyebabkan kerugian perusahaan. Penerapan GCG pada PT akan membuat PS minoritas merasa aman dan terlindungi, serta terjamin kepentingannya. Oleh sebabitu, perlindungan hukum bagi PS minoritas dalam sistem GCG menjadi begitu penting.

\section{KESIMPULAN}

Kedudukan pemegang saham minoritas dengan prinsip one share one vote berkaitan dengan pengambilan keputusan dalam rancangan merger pada RUPS lebih lemah dari pemegang saham mayoritas, dikarenakan perbedaan jumlah kepemilikan saham. Terhadap pemegang saham minoritas yang tidak setuju terhadap keputusan tersebut, diberikan hak yang disebut appraisal right, yaitu hak untuk menjual sahamnya harga yang wajar. appraisal right diatur dalam (Pasal 126 ayat (2) juncto Pasal 62), serta berhak mengajukan gugatan terhadap Perseroan apabila dirugikan karena tindakan Perseroan sebagai akibat keputusan RUPS, Direksi, dan/atau Komisaris.Namun hak tersebut tidak menghentikan proses merger tersebut. Sangat mungkin terjadi bahwa pemegang saham minoritas menjual sahamnya karena keadaan terpaksa yang sengaja dikondisikan oleh pemegang saham mayoritas yang tidak beritikad baik. agar proses merger dapat berjalan dengan lancar dan tepat waktu sesuai dengan aturan yang berlaku sehingga tercapai unsur fairness terhadap pemegang saham minoritas. Maka berkaitan dengan perlindungan pemegang saham minoritas terhadap merger harus lebih disempurnakan lagi baik itu penambahan aturan maupun pembenahan lagi untuk mengakomodir hak-hak dan kepentingannya terhadap

\footnotetext{
${ }^{15}$ Aripin, Op.Cit, hlm. 52
} 
pemegang saham minoritas dalam merger Perseroan terbatas sebagaimana diisyaratkan oleh prinsip Good Corporate Governance.

\section{DAFTAR PUSTAKA}

Adrian Sutedi. 2015, Buku Pintar Hukum Perseroan Terbatas, Jakarta, Raih Asa Sukses.

Aripin. 2009, Perlindungan Hukum Terhadap Pemegang Saham Minoritas Perseroan Terbatas Terbuka Dalam Rangka Menciptakan Kepastian Hukum Sebagai Sarana Peningkatan Iklim Investasi Di Indonesia, skripsi, Fakultas Hukum Universitas Sebelas Maret Surakarta

Dewi Nurjanah. 2007, Pengaruh Pemilihan Metode Untuk Merger dan Akuisisi Terhadap Volume Perdagangan Saham Perusahaan Publik yang Terdaftar di BEJ Periode 2000-2006, Skripsi Fakultas Ekonomi UMS

Hasnati. 2004, Peranan Komite Audit dalam Organ Perseroan Terbatas dalam Kerangka Good Corporate Governance, Yogyakarta, FH UII Press

Marcel Go, Akuisisi bisnis dan pengelolaan. Rineka Cipta, Jakarta, 1992. hlm. 25-26.

Munir Fuady, 2005 Perlindungan Pemegang Saham Minoritas, Bandung, CV. Utomo

M.Yahya Harahap. 2009, Hukum Perseroan Terbatas, Jakarta, Sinar Grafika

Syofia Gayatri, Sunaryo, Dianne Eka R. 2018, Perlindungan Hukum Terhadap Pemegang Saham Minoritas Pada Perusahaan Terbuka Di Indonesia, Pactum Law Journal, Vol 1 No. 2

Wina Bismar Nasution, Suhaidi, Mahmul Siregar. 2018, Analisis Yuridis Perlindungan Hukum terhadap Pemegang Saham Minoritas dalam Perusahaan Terbuka, USU Law Journal, Vol.6. No.5 